\title{
Comparing in vitro maturation rates in buffalo and cattle oocytes and evaluating the effect of CAMP modulators on maturation and subsequent developmental competence
}

\author{
Abdelrahman Abdulkarim ${ }^{1}$, Ahmed Balboula ${ }^{1}$, Magdy Badr ${ }^{2}$, Wael Bedir ${ }^{1}$, Mohamed Elmetwaly ${ }^{1}$, Samy Zaabel ${ }^{1}$ \\ *Theriogenology Department, Faculty of Veterinary Medicine, Mansoura University, Egypt \\ **Artificial Insemination and Embryo Transfer Department, Animal Reproduction Research Institute, Al Haram, Giza, Egypt
}

\section{ARTICLE HISTORY}

Received: 16.08 .2021

Revised: 06.09.2021

Accepted: 16.09 .2021

Corresponding author: Samy Zaabel

mmetwally@mans.edu.eg

\begin{abstract}
Objective: The purpose of this research was to compare the kinetics and meiotic advancement of cattle and buffalo oocytes, as well as to see how cAMP modulators affected the meiotic progression status of cattle and buffalo oocytes during the oocyte collection process.

Design: comparing maturation stages times in buffalo and cattle oocytes. Cattle and buffalo oocytes were collected, separated into two groups (standard IVM and extended IVM), and cultivated for five hours in $5 \%$ $\mathrm{CO} 2$ at $39^{\circ} \mathrm{C}$. The sample times for extended IVM are 8, 15, 18, 22, 24, and 30 hours. The nuclear status of each oocyte was assessed to determine how far it had matured at each time sample. Then after, study the effect of cAMP modulators on maturation rates of cattle and buffalo oocytes.

Procedures: Standard IVM samples were taken at different maturation times, commencing at $8 \mathrm{~h}$ and ending at $24 \mathrm{~h}$, while extended IVM samples were taken at $30 \mathrm{~h}$. COCs were placed in a $15-\mathrm{mL}$ sterile centrifuge tube with a warmed 3 percent sodium citrate solution and vortexed at maximum speed for 4 to 8 minutes as needed to remove all cumulus cells before being placed in a warm water bath at $39^{\circ} \mathrm{C}$ for 5 minutes. After that, the oocytes were mounted on a slide and placed in Coplin jars with a 3:1 methanol/acetic acid solution. Results: At any stage of sampling, the percentage of oocytes arrested at the GV stage did not differ significantly between cattle and buffalo oocytes. Furthermore, there was no significant difference between cattle and buffalo oocytes in terms of the percentage of oocytes that reached the MI stage. Moreover, the percentage of oocytes arrested at the GV stage did not differ substantially between cattle and buffalo oocytes when maturation was extended using CAMP modulators at all stages of sampling.

Conclusion and clinical relevance: Modulating cAMP during oocyte maturation can change oocyte kinetics and increase developmental competence by boosting fertilization, cleavage, and morula rates. Furthermore, there is no significant differences in maturation rates between buffalo and cattle oocytes.
\end{abstract}

Keywords: Cattle and buffalo oocytes, Extended maturation, cAMP modulators.

\section{INTRODUCTION}

Buffalo is an important livestock resource in many Asian and Mediterranean countries [1,2]. In vitro embryo production (IVEP) efficiency in buffalo is lower than in cattle, according to research, and this could be improved further by selecting highquality oocytes and/or improving the in vitro embryo culture system [3] [4] [5] [6]. The lack of synchronization between nuclear and cytoplasmic maturation, as well as insufficient cytoplasmic maturation, results in oocytes matured in vitro having lower developmental competence than those matured in vivo $[3,4,6,7]$. Despite extensive research into factors affecting oocyte maturation in mice and other animals, the molecular mechanism governing oocyte maturation in buffalo remains unknown [8-11].
The goal of this study was to compare the kinetics and meiotic progression of cattle and buffalo oocytes, as well as to assess the effect of cAMP modulators on the meiotic progression status of cattle and buffalo oocytes during oocyte collection. Extend the maturation period of buffalo oocytes to see how it affects the rates of fertilization, cleavage, morula formation, and blastocyst formation.

\section{MATERIALS AND METHODS}

Unless otherwise stated all chemicals used were obtained from Sigma Chemical Co (St. Louis, MO, USA).

\subsection{Oocytes recovery and IVM}

The recovery of the buffalo oocytes invitro was done according to Mostagir et al. 2019 [2]. In a nutshell, ovaries from buffaloes with seemingly normal reproductive organs were 
collected within 30 minutes of slaughter and evisceration. Within 1-2 hours of slaughter, the ovaries were kept in warm normal saline with $(100 \mathrm{IU}$ penicillin and $100 \mathrm{~g}$ streptomycin/ml) and transported to the lab. Aspiration of medium-sized ovarian follicles yielded cumulus-oocyte complexes (COCs) (2-8 mm). For the study, COCs with evenly granulated oocytes surrounded by multi-layered compact cumulus cells were chosen and washed three times in phosphate buffer saline. A 100 I drop of TCM 199 supplemented with $10 \%$ heat-inactivated foetal calf serum, $10 \mathrm{~g} / \mathrm{ml} \mathrm{LH}, 5 \mathrm{~g} / \mathrm{ml}$ $\mathrm{FSH}$, and $1 \mathrm{~g} / \mathrm{ml}$ estradiol-17 is given to each of the 10-15 COCs. Mineral oil is used to cover the drops, which are then incubated for $20-22$ hours at $38.5^{\circ} \mathrm{C}$ in the air with a maximum humidity of 5 percent $\mathrm{CO} 2$.

\subsection{Extension of maturation by $c A M P$ modulators}

COCs were washed four times in a pre-IVM medium containing (cAMP modulators; forskolin FSK, and 3-isobutyl-1methylxanthine IBMX), and then incubated in this medium for two hours at $39^{\circ} \mathrm{C}$ in a non-CO2 incubator. COCs were washed four times in an extended IVM medium with cilostamide after being washed in HEPES-TALP. COCs were then divided into six groups for each of the 6-time samples, and each group of ten to fifteen COCs was placed in 50 I drops of IVM media and cultured for the required time in $5 \% \mathrm{CO} 2$ at $39^{\circ} \mathrm{C}$ and humidity of $95 \%$ in the air.

\subsection{Sampling and staining}

Samples were taken at different maturation times for standard IVM, starting at $8 \mathrm{~h}$ and ending at $24 \mathrm{~h}$, and at $30 \mathrm{~h}$ for extended IVM. COCs were placed in a warmed 3 percent sodium citrate solution in a $15-\mathrm{mL}$ sterile centrifuge tube and vortexed at maximum speed for 4 to 8 minutes as needed to remove all cumulus cells in a warm water bath at $39^{\circ} \mathrm{C}$ for 5 minutes. Oocytes were then fixed on a slide and placed in Coplin jars containing a 3:1 methanol/acetic acid solution that had been prepared previously. Oocyte slides were kept in a methanol/acetic acid solution for 24 to 72 hours. After that, the oocytes were stained with $1 \%$ aceto-orcein. Each oocyte's nuclear status was determined by looking at the slides under a microscope at a magnification of 20X. The oocytes were divided into three stages: GVBD (germinal vesicle breakdown), MI (metaphase I), and M II (metaphase II).

\subsection{In vitro fertilization (IVF)}

As described by Castellano et al. 2021 [12] motile spermatozoa were separated by the swim-up technique in the fertilization medium, modified Tyrode's Albumin-LactatePyruvate (TALP) containing $6 \mathrm{mg} / \mathrm{ml}$ of bovine serum albumin (BSA), for 1 hour. Gametes were co-incubated in the fertilization drops under sterile mineral oil for 18 hours at $39^{\circ} \mathrm{C}$ in an atmosphere of $5 \% \mathrm{CO} 2$ in the air with maximum humidity after appropriate dilution.
Presumptive zygotes were gently pipetted out of cumulus cells and transferred to the culture medium synthetic oviductal fluid (SOF) (with $1 \mathrm{mM}$ glutamine, 1\% nonessential amino acids, and 1\% MEM essential amino acids) and covered with mineral oil for 7 days at $38.5^{\circ} \mathrm{C}$ in a $\mathrm{CO} 2$ atmosphere with maximum humidity [2]. The cleavage, morula, and blastocyst rates were calculated according to $[13,14]$.

\subsection{Experimental Design}

2.6.1. Experiment 1: comparing maturation stages times in buffalo and cattle oocytes

Oocytes from cattle and buffalo were collected, divided into two groups (standard IVM and extended IVM), cultured in $5 \% \mathrm{CO} 2$ at $39^{\circ} \mathrm{C}$ for five hours, and sampled. Standard IVM sample times are $8,15,18,22$, and 24 hours. Extended IVM sample times are $8,15,18,22,24$, and 30 hours. Each oocyte's nuclear status was evaluated to determine how far the oocyte had developed at each time sample.

\subsubsection{Experiment 2-A: effect of cAMP modulators on maturation rates of cattle and buffalo oocytes}

During oocyte collection for the extended IVM treatment, CAMP modulators FSK and IBMX were added to the oocyte holding medium (HEPES-TALP). Both cattle and buffalo oocytes were separated into two groups: standard IVM and extended IVM. During oocyte collection, the control treatment consisted of standard HEPES-TALP holding medium before moving the oocytes into a standard IVM medium. During oocyte collection, the extended IVM consisted of a HEPES-TALP holding media supplemented with FSK and IBMX. Oocytes were placed in preIVM for 2 hours before being placed in IVM for 30 hours.

The rest of the experiment was carried out in the same manner as the first. All oocytes in IVM were cultured at $39^{\circ} \mathrm{C}$ in $5 \% \mathrm{CO} 2$ and sampled at regular intervals. Oocytes were stained with aceto-orcein after the CoCs were removed. At each time sample, the nuclear status was determined to determine oocyte development.

\subsubsection{Experiment 2-B: effect of addition of CAMP modulators during maturation on the developmental competence of buffalo oocytes}

To determine the effect of extended maturation time on in vitro fertilization and embryo development rate, oocytes that matured in vitro in control standard IVM or extended IVM were in vitro fertilized and cultured.

\subsection{Statistical analysis}

Each experiment was replicated at least three times. Student's t-Test and one-way ANOVA were used to evaluate the differences between groups according to Elmetwally 2012 [15]; Gohar et al. 2018 [16], Elmetwally et al.2018; 2019; 2020 [1719]. . The differences of $p<0.05$ were considered significant.

\subsection{In vitro culture (IVC)}




\section{RESULTS}

\subsection{Experiment 1: comparing maturation stages times in} buffalo and cattle oocytes

As shown in table 1, the percentage of oocytes arrested at the GV stage did not differ significantly between cattle and buffalo oocytes at any stage of sampling. Furthermore, there was no significant difference in the percentage of oocytes that reached the Ml stage between cattle and buffalo oocytes. Furthermore, there was no significant difference in the percentage of oocytes that reached the MII stage between cattle and buffalo oocytes, except after 22 hours, when buffalo oocytes had a significantly higher percentage of oocytes that reached the MII stage than cattle oocytes.

Table 1. The normal in vitro maturation rates in different stages in buffalo and cattle oocytes.

\begin{tabular}{|c|c|c|c|c|}
\hline Time & & GV & MI & MII \\
\hline \multirow[t]{2}{*}{8 hours } & Cattle & $\begin{array}{l}42.77 \pm \\
5.80\end{array}$ & $\begin{array}{l}24.66 \pm \\
13.007\end{array}$ & 0 \\
\hline & Buffalo & $\begin{array}{l}40.51 \pm \\
1.58\end{array}$ & $\begin{array}{l}30.74 \pm \\
7.7\end{array}$ & 0 \\
\hline \multirow[t]{2}{*}{15 hours } & Cattle & $\begin{array}{l}10.647 \pm \\
1.226\end{array}$ & $\begin{array}{l}72.697 \pm \\
3.901\end{array}$ & 0 \\
\hline & Buffalo & $\begin{array}{l}15.190 \pm \\
4.865\end{array}$ & $\begin{array}{l}79.090 \pm \\
3.027\end{array}$ & 0 \\
\hline \multirow[t]{2}{*}{18 hours } & Cattle & $\begin{array}{l}6.403 \pm \\
3.857\end{array}$ & $\begin{array}{c}24.607 \pm \\
9.206\end{array}$ & $\begin{array}{c}28.987 \pm \\
4.674\end{array}$ \\
\hline & Buffalo & $\begin{array}{l}6.840 \pm \\
3.423\end{array}$ & $\begin{array}{l}19.573 \pm \\
6.939\end{array}$ & $\begin{array}{l}38.423 \pm \\
3.619\end{array}$ \\
\hline \multirow[t]{2}{*}{22 hours } & Cattle & $\begin{array}{l}4.603 \pm \\
2.306\end{array}$ & $\begin{array}{l}10.570 \pm \\
2.375\end{array}$ & $\begin{array}{c}41.743 \pm \\
3.216\end{array}$ \\
\hline & Buffalo & $\begin{array}{l}4.737 \pm \\
2.472\end{array}$ & $\begin{array}{l}9.897 \pm \\
1.712\end{array}$ & $\begin{array}{l}61.527 \pm \\
6.789^{* *}\end{array}$ \\
\hline \multirow[t]{2}{*}{24 hours } & Cattle & 0 & $\begin{array}{l}9.893 \pm \\
3.055\end{array}$ & $\begin{array}{l}75.963 \pm \\
4.167\end{array}$ \\
\hline & Buffalo & 0 & $\begin{array}{l}7.513 \pm \\
1.881\end{array}$ & $\begin{array}{c}77.987 \pm \\
1.105\end{array}$ \\
\hline
\end{tabular}

\subsection{Experiment 2: effect of cAMP modulators on maturation rates of cattle and buffalo oocytes}

As shown in table 2, after the extension of maturation by cAMP modulators at all stages of sampling, the percentage of oocytes that were arrested at the GV stage did not vary significantly between cattle and buffalo oocytes. Moreover, the percentage of oocytes that reached the Ml stage did not vary significantly between cattle and buffalo oocytes. Furthermore, the percentage of oocytes that reached the MII stage did not vary significantly between cattle and buffalo oocytes.

\subsection{Experiment 2-B: effect of addition of CAMP modulators during maturation on the developmental competence of buffalo oocytes}

Table 2. Effect of cAMP modulators on maturation rates of cattle and buffalo oocytes.

\begin{tabular}{|c|c|c|c|c|}
\hline & & GV & MI & MII \\
\hline \multirow[t]{2}{*}{8 hours } & Cattle & $\begin{array}{c}64.043 \pm \\
5.541\end{array}$ & $\begin{array}{l}15.310 \pm \\
1.505\end{array}$ & 0 \\
\hline & Buffalo & $\begin{array}{c}60.343 \pm \\
3.296\end{array}$ & $\begin{array}{c}11.013 \pm \\
3.294\end{array}$ & 0 \\
\hline \multirow[t]{2}{*}{15 hours } & Cattle & $\begin{array}{l}40.0 \pm \\
3.851\end{array}$ & $\begin{array}{l}56.520 \pm \\
6.469\end{array}$ & 0 \\
\hline & Buffalo & $\begin{array}{l}42.070 \pm \\
7.727\end{array}$ & $\begin{array}{c}54.480 \pm \\
16.721\end{array}$ & 0 \\
\hline \multirow[t]{2}{*}{18 hours } & Cattle & $\begin{array}{l}14.167 \pm \\
3.751^{b}\end{array}$ & $\begin{array}{l}21.107 \pm \\
1.377^{\mathrm{a}}\end{array}$ & $\begin{array}{l}23.283 \pm \\
6.413\end{array}$ \\
\hline & Buffalo & $\begin{array}{c}23.240 \pm \\
5.055^{\mathrm{a}}\end{array}$ & $\begin{array}{l}24.113 \pm \\
2.696\end{array}$ & $\begin{array}{c}19.423 \pm \\
4.691\end{array}$ \\
\hline \multirow[t]{2}{*}{22 hours } & Cattle & $\begin{array}{l}3.813^{b} \pm \\
3.751\end{array}$ & $\begin{array}{l}16.203^{b} \pm \\
2.017\end{array}$ & $\begin{array}{c}34.653 \pm \\
5.026\end{array}$ \\
\hline & Buffalo & $\begin{array}{l}12.067^{\mathrm{a}} \pm \\
5.055\end{array}$ & $\begin{array}{l}21.943^{a} \pm \\
6.091\end{array}$ & $\begin{array}{l}35.283 \pm \\
8.937\end{array}$ \\
\hline \multirow[t]{2}{*}{24 hours } & Cattle & $\begin{array}{l}4.860^{b} \pm \\
2.503\end{array}$ & $\begin{array}{c}8.517^{b} \pm \\
1.769\end{array}$ & $\begin{array}{l}54.173^{b} \pm \\
1.044\end{array}$ \\
\hline & Buffalo & $\begin{array}{l}12.367^{a} \pm \\
2.419\end{array}$ & $\begin{array}{c}13.6^{\mathrm{a}} \pm \\
3.599\end{array}$ & $\begin{array}{l}59.943^{\mathrm{a}} \pm \\
3.711\end{array}$ \\
\hline \multirow[t]{2}{*}{28 hours } & Cattle & $\begin{array}{l}4.463^{b} \pm \\
2.246\end{array}$ & $\begin{array}{l}8.473 \pm \\
2.017\end{array}$ & $\begin{array}{l}41.037^{b} \pm \\
5.026\end{array}$ \\
\hline & Buffalo & $\begin{array}{l}12.490^{\mathrm{a}} \pm \\
5.603\end{array}$ & $\begin{array}{l}9.490 \pm \\
3.591\end{array}$ & $\begin{array}{l}52.767^{\mathrm{a}} \pm \\
7.022\end{array}$ \\
\hline
\end{tabular}

Values with different letters in the same time stage of sampling are significantly different between cattle and buffalo $(P<0.05)$.

Table 3. Effect of addition of cAMP modulators during maturation on the developmental competence of buffalo oocytes

\begin{tabular}{lll} 
& 24h & $28 \mathrm{~h}$ \\
\hline Fertilization rate & $44.09 \pm 4.86$ & $63.46 \pm 3.7 *$ \\
Cleavage rate & $35.46 \pm 2.03$ & $56.22 \pm 6.72 *$ \\
Morula rate & $16.45 \pm 0.8743$ & $29.12 \pm 3.659^{*}$ \\
Blastocyst rate & $6.537 \pm 3.294$ & $15.26 \pm 4.062^{*}$
\end{tabular}

Values with astrikes in the same time stage of sampling are significantly different between cattle and buffalo $(\mathrm{P}<0.05)$.

As shown in table 3 , extending the IVM for $28 \mathrm{~h}$ significantly increased the percentage of fertilized oocytes, when compared to in vitro matured oocytes that were incubated for $24 \mathrm{~h}$.

\section{DISCUSSION}

During mammalian oogenesis, the oocyte is arrested at the dictate or germinal vesicle (GV) stage for a long time, then undergoes germinal vesicle breakdown (GVBD) and progresses to the metaphase I (MI) stage, followed by extrusion of the first polar body and arrest at the metaphase II (MII) stage $[\mathbf{8 , 2 0 , 2 1 ]}$. The identification of potential predictors of oocyte developmental competence and the elucidation of molecular 
mechanisms regulating oocyte maturation will aid us in improving the quality of oocytes matured in vitro $[22,23]$.

In the first 15 hours of the IVM, there was no significant difference in maturation rates between cattle and buffalo oocytes, according to the findings. After 22 hours of maturation, however, a significant difference in maturation rates was observed. Buffalo oocytes matured at a faster rate than cattle oocytes. However, after 24 hours of maturation, there was no discernible difference between the two species. Buffalo oocytes reached nuclear maturation faster than cattle oocytes, according to these findings.

The higher maturation rate observed in buffalo than cattle oocytes doesn't mean that developmental competence of buffalo oocytes will be higher than cattle [4]. As The data of in vitro embryo production (IVEP) in buffalo showed a lower efficiency compared to cattle. This rapid maturation rate can explain the developmental competence of in vitro matured oocytes is lower than in vivo matured as mentioned before by [4,24-26].

These findings also suggest that buffalo's lower developmental competence may be due to rapid nuclear maturation prior to the completion of all cytoplasmic maturation events.

After observing the normal maturation in buffalo and cattle oocytes, the effect of elongation on the time of maturation has been evaluated. Meiotic inhibitors were added to the maturation medium then the maturation rates have been examined at different stages. The results revealed that no significant difference appeared in the maturation rates between cattle and buffalo oocytes at different times of maturation [27-29].

The findings showed that using CAMP modulators to extend the maturation process in buffalo oocytes until 28 hours improved developmental competence by increasing fertilisation, cleavage, and morula rates. These findings were consistent with Gilchrist, 2010 [30,31], who suggested that modulating CAMP during oocyte IVM could be a solution to the current developmental competence gap between IVMproduced oocytes and those matured in vivo [32-34]. As a result, increasing fertilisation, cleavage, and morula rates by modulating cAMP during oocyte maturation can modify oocyte kinetics and improve developmental competence.

\section{Acknowledgment}

My gratitude to the coworkers at Artificial Insemination and Embryo Transfer Department, Animal Reproduction Research Institute, Al Haram, Giza, Egypt.

\section{Conflict of interest}

Authors declare that they have no conflict of interest

\section{Authors' contribution}

Abdelrahman Abdulkarim: Methodology, data collection, hormones infusion, writing, Ahmed Balboula: Conceptualization, Methodology, Data curation, Writing, Editing, Revision, and Supervision; Magdy Badr: data analysis, writing; Wael Eldomany: data analysis, writing, Samy Zaabel: Conceptualization, Methodology, Data curation, Writing, Editing, Revision, and Supervision.

\section{REFERENCES}

[1] Shafiei Sheykhani HR, Batavani RA, Najafi GR. Protective effect of leptin on induced apoptosis with trichostatin A on buffalo oocytes. Vet Res Forum 2016;7:99-104.

[2] Mostagir A, Elmetwally M, Montaser A, Zaabel S. Effects of L Carnitine and Cryoprotectants on Viability Rate of Immature Buffalo Oocytes in vitro After Vitrification. AJVS 2019;62:45. https://doi.org/10.5455/ajvs.57457.

[3] Malpotra S, Singh MK, Palta P. MeDIP-sequencing for profiling global DNA methylation in buffalo embryos produced by in vitro fertilization. Anim Biotechnol 2021:1-17. https://doi.org/10.1080/10495398.2021.1981356.

[4] Currin L, Baldassarre H, Bordignon V. In Vitro Production of Embryos from Prepubertal Holstein Cattle and Mediterranean Water Buffalo: Problems, Progress and Potential. Animals (Basel) 2021;11. https://doi.org/10.3390/ani11082275

[5] da Silva JCB, Alves MBR, Bridi A, Bohrer RC, Escobar GSL, de Carvalho JABA, et al. Reproductive seasonality influences oocyte retrieval and embryonic competence but not uterine receptivity in buffaloes. Theriogenology 2021;170:77-84. https://doi.org/10.1016/j.theriogenology.2021.04.019.

[6] Yang C-Y, Zheng $\mathrm{H}-\mathrm{Y}$, Abdelnour SA, Li L-Y, Shokrollahi B, Tang L-P, et al. Molecular signatures of in vitro produced embryos derived from ovum pick up or slaughterhouse oocytes in buffalo. Theriogenology 2021;169:14-20. https://doi.org/10.1016/j.theriogenology.2021.03.025.

[7] Almeida J, Neves BP, Brito MF, Freitas RF, Lacerda LG, Grapiuna LS, et al. Impact of in vitro fertilization by refrigerated versus frozen buffalo semen on developmental competence of buffalo embryos. Anim Reprod 2020;17:e20200033. https://doi.org/10.1590/1984-3143-AR2020-0033.

[8] Chen L, Zhai L, Qu C, Zhang C, Li S, Wu F, et al. Comparative Proteomic Analysis of Buffalo Oocytes Matured in vitro Using iTRAQ Technique. Sci Rep 2016;6:31795. https://doi.org/10.1038/srep31795.

[9] Walter J, Huwiler F, Fortes C, Grossmann J, Roschitzki B, Hu J, et al. Analysis of the equine "cumulome" reveals major metabolic aberrations after maturation in vitro. BMC Genomics 2019;20:588. https://doi.org/10.1186/s12864-019-5836-5.

[10] Desmet KL, Marei WFA, Richard C, Sprangers K, Beemster GTS, Meysman $P$, et al. Oocyte maturation under lipotoxic conditions induces carryover transcriptomic and functional alterations during post-hatching development of good-quality blastocysts: novel insights from a bovine embryo-transfer model. Hum Reprod 2020;35:293-307. https://doi.org/10.1093/humrep/dez248.

[11] Gegenfurtner K, Flenkenthaler F, Fröhlich T, Wolf E, Arnold GJ. The impact of transcription inhibition during in vitro maturation on the proteome of bovine oocytest. Biol Reprod 2020;103:1000-11. https://doi.org/10.1093/biolre/ioaa149.

[12] Castellano L, Arroyo-Salvo CA, Chiarante N, Alonso CAI, Lottero-Leconte $\mathrm{RM}$, Vernaz ZJ, et al. Evaluation of $\alpha 5 \beta 1$ integrin as a candidate marker for fertility in bull sperm samples. Theriogenology 2021;168:66-74. https://doi.org/10.1016/j.theriogenology.2021.04.001.

[13] Xu H-Y, Geng S-S, Li T-T, Fu Q, Lu S-S, Liang X-W, et al. Maturation of buffalo oocytes in vitro with acetyl-L-carnitine improves cryotolerance due to changes in mitochondrial function and the membrane lipid profile. 
Reprod Fertil Dev 2019;31:386-94. https://doi.org/10.1071/RD18102.

[14] Eswari S, Sai Kumar G, Sharma GT. Expression of mRNA encoding leukaemia inhibitory factor (LIF) and its receptor (LIFR $\beta$ ) in buffalo preimplantation embryos produced in vitro: markers of successful embryo implantation. Zygote 2013;21:203-13. https://doi.org/10.1017/S0967199412000172.

[15] Elmetwally MA. Clinical applicability of non-invasive Doppler ultrasonography in small ruminants throughout pregnancy. Doctoral dissertation. Hanover University of Veterinary Medicine, 2012.

[16] Gohar MA, Elmetwally MA, Montaser A, Zaabel SM. Effect of Oxytetracycline Treatment on Postpartum Reproductive Performance in Dairy Buffalo-Cows with Retained Placenta in Egypt. JVHC 2018;1:45-53. https://doi.org/10.14302/issn.2575-1212.jvhc-18-2146.

[17] Elmetwally MA, Halawa AA, Lenis YY, Tang W, Wu G, Bazer FW. Effects of Bisphenol-A on proliferation and expression of genes related to synthesis of polyamines, interferon tau and insulin-like growth factor 2 by ovine trophectoderm cells. Reprod Toxicol 2018;78:90-6. https://doi.org/10.1016/j.reprotox.2018.04.004.

[18] Elmetwally MA, Halawa AA, Lenis YY, Tang W, Wu G, Bazer FW. Effects of BPA on expression of apoptotic genes and migration of ovine trophectoderm (oTr1) cells during the peri-implantation period of pregnancy. Reprod 2019;83:73-9. https://doi.org/10.1016/j.reprotox.2018.12.001.

[19] Elmetwally MA, Elshopakey GE, El-Desouky AM, Eldomany WB, Bazer FW. Serum biochemical profile in buffalo endometritis and impact of treatment with PGF2 $\alpha$ and intrauterine gentamicin infusion on postpartum reproductive performance. Trop Anim Health Prod 2020;52:3697-706. https://doi.org/10.1007/s11250-020-02406-3.

[20] Fu Q, Liu Z-F, Huang Y-L, Lu Y-Q, Zhang M. Comparative Proteomic Analysis of Mature and Immature Oocytes of the Swamp Buffalo (Bubalus bubalis). Int J Mol Sci 2015;17. https://doi.org/10.3390/ijms17010094.

[21] Talbot NC, Powell AM, Caperna TJ, Garrett WM. Proteomic analysis of the major cellular proteins of bovine trophectoderm cell lines derived from IVP, parthenogenetic and nuclear transfer embryos: Reduced expression of annexins I and II in nuclear transfer-derived cell lines. Anim Reprod Sci 2010;120:187-202. https://doi.org/10.1016/j.anireprosci.2010.03.009.

[22] Ellederova Z, Halada P, Man P, Kubelka M, Motlik J, Kovarova H. Protein patterns of pig oocytes during in vitro maturation. Biol Reprod 2004;71:1533-9. https://doi.org/10.1095/biolreprod.104.030304.

[23] Bijttebier J, Tilleman K, Dhaenens M, Deforce D, Van Soom A, Maes D. Comparative proteome analysis of porcine follicular fluid and serum reveals that excessive alpha(2)-macroglobulin in serum hampers successful expansion of cumulus-oocyte complexes. Proteomics 2009;9:4554-65. https://doi.org/10.1002/pmic.200900270.

[24] Baldassarre H. Laparoscopic Ovum Pick-Up Followed by In Vitro Embryo Production and Transfer in Assisted Breeding Programs for Ruminants. Animals (Basel) 2021;11. https://doi.org/10.3390/ani11010216.

[25] Gutiérrez-Añez JC, Lucas-Hahn A, Hadeler K-G, Aldag P, Niemann H. Melatonin enhances in vitro developmental competence of cumulusoocyte complexes collected by ovum pick-up in prepubertal and adult dairy cattle. Theriogenology 2021;161:285-93. https://doi.org/10.1016/j.theriogenology.2020.12.011.

[26] McGrice H, Kelly JM, Kleemann DO, Kind KL, Hampton AJ, Hannemann P, et al. Plasma anti-Müllerian hormone concentration as a predictive endocrine marker for selection of donor lambs to improve success in juvenile in vitro embryo transfer programs. Reprod Fertil Dev 2020;32:383-91. https://doi.org/10.1071/RD18498.

[27] Currin L, Michalovic L, Bellefleur A-M, Gutierrez K, Glanzner W, Schuermann $Y$, et al. The effect of age and length of gonadotropin stimulation on the in vitro embryo development of Holstein calf oocytes.
Theriogenology

https://doi.org/10.1016/j.theriogenology.2017.08.011.

[28] Paramio MT, Izquierdo D. Current status of in vitro embryo production in sheep and goats. Reprod Domest Anim 2014;49 Suppl 4:37-48. https://doi.org/10.1111/rda.12334.

[29] Mao J, Wu G, Smith MF, McCauley TC, Cantley TC, Prather RS, et al. Effects of culture medium, serum type, and various concentrations of folliclestimulating hormone on porcine preantral follicular development and antrum formation in vitro. Biol Reprod 2002;67:1197-203. https://doi.org/10.1095/biolreprod67.4.1197.

[30] Gilchrist RB. Recent insights into oocyte-follicle cell interactions provide opportunities for the development of new approaches to in vitro maturation. Reprod Fertil Dev 2011;23:23-31. https://doi.org/10.1071/RD10225.

[31] Luciano AM, Lodde V, Beretta MS, Colleoni S, Lauria A, Modina S. Developmental capability of denuded bovine oocyte in a co-culture system with intact cumulus-oocyte complexes: role of cumulus cells, cyclic adenosine 3',5'-monophosphate, and glutathione. Mol Reprod Dev 2005;71:389-97. https://doi.org/10.1002/mrd.20304.

[32] Saugandhika S, Sharma V, Malik H, Saini S, Bag S, Kumar S, et al. Expression and purification of buffalo interferon-tau and efficacy of recombinant buffalo interferon-tau for in vitro embryo development. Cytokine 2015;75:186-96. https://doi.org/10.1016/j.cyto.2015.03.012.

[33] Yan L, Li H, Shi Z. Immunization against inhibin improves in vivo and in vitro embryo production. Anim Reprod Sci 2015;163:1-9. https://doi.org/10.1016/j.anireprosci.2015.11.001.

[34] Tatham BG, Feehan T, Pashen R. Buffalo and cattle hybrid embryo development is decreased by caffeine treatment during in vitro fertilization. Theriogenology 2003;59:709-17. https://doi.org/10.1016/s0093-691x(02)01124-x. 